\title{
ANALYSIS OF PASSION FRUIT RINDS (Passiflora edulis): ISOORIENTIN QUANTIFICATION BY HPTLC AND EVALUATION OF ANTIOXIDANT (RADICAL SCAVENGING) CAPACITY
}

\author{
Maria Luiza Zeraik and Janete H. Yariwake* \\ Instituto de Química de São Carlos, Universidade de São Paulo, CP 780, 13560-970 São Carlos - SP, Brasil \\ Jean-Noël Wauters, Monique Tits and Luc Angenot \\ Département de Pharmacie, Université de Liège, CHU, Tour 4 B36, B-4000 Liège 1, Belgium
}

Recebido em 15/6/11; aceito em 15/9/11; publicado na web em 8/11/11

\begin{abstract}
ANALYSIS OF PASSION FRUIT RINDS (Passiflora edulis): ISOORIENTIN QUANTIFICATION BY HPTLC AND EVALUATION OF ANTIOXIDANT (RADICAL SCAVENGING) CAPACITY. The content of isoorientin in passion fruit rinds (Passiflora edulis fo. flavicarpa O. Degener) was determined by HPTLC (high performance thin layer chromatography) with densitometric analysis. The results revealed a higher amount of isoorientin in healthy rinds of $P$. edulis $\left(92.275 \pm 0.610 \mathrm{mg} \mathrm{L}^{-1}\right)$ than in rinds with typical symptoms of PWV (Passion fruit Woodiness Virus) infection $\left(28.931 \pm 0.346 \mathrm{mg} \mathrm{L}^{-1}\right)$. The HPTLC data, allied to assays of radical scavenging activity, suggest the potential of $P$. edulis rinds as a natural source of flavonoids or as a possible functional food.
\end{abstract}

Keywords: Passiflora edulis; HPTLC; antioxidant flavonoides.

\section{INTRODUCTION}

Passiflora edulis fo. flavicarpa O. Degener is native to Brazil, the world's largest producer of this species. In Brazil, where the species is known popularly due to its acidity as "sour maracujá" ("maracujá azedo"), or simply "maracujá", it is widely cultivated and used in the food industry (processed juices). ${ }^{1}$ Passion fruit rinds represent about half of the fruit's mass, and because of the high volume of juice production, the rinds representa a major waste product and a substantial burden to the environment. ${ }^{2}$

Earlier studies reported that the chemical composition of passion fruit rind has a higher nutrient content than the pulp. ${ }^{3}$ Moreover, the rinds are a good source of fiber and pectin. ${ }^{4}$ Flavonoids, mainly $C$-glycosylflavones, are the major constituents of $P$. edulis leaves and pulp, ${ }^{5,6}$ and a HPLC method was reported for the quantification of isoorientin and total flavonoids in P. edulis pulp: the content of isoorientin and total flavonoids $\left[(16.226 \pm 0.050) \mathrm{mg} \mathrm{L}^{-1}\right.$ and $(158.037 \pm 0.602) \mathrm{mg}$ $\mathrm{L}^{-1}$, respectively] suggested that $P$.edulis fruits may be comparable with other flavonoid food sources such as orange juice or sugarcane juice. ${ }^{7}$

Polyphenols, including flavonoids, provide beneficial health effects that are attributed to their antioxidant and chelating abilities. ${ }^{8}$ Therefore, it is important to study natural sources of flavonoids and evaluate their activity to assess their potential as possible functional foods.

Ichimura et al. ${ }^{9}$ analysed the flavonoids luteolin $\left(20 \mu \mathrm{g} \mathrm{g}^{-1}\right.$ dry weight) and luteolin-6- $C$-glucoside (41 $\mu \mathrm{g} \mathrm{g}^{-1}$ dry weight) in the methanol extract of $P$. edulis rinds, and also $\gamma$-aminobutyric acid (GABA; $2.4 \mathrm{mg}$ $\mathrm{g}^{-1}$ dry weight) by LC-MS/MS (liquid chromatography tandem mass spectrometry). Recently, the antioxidant activity of methanol extracts from $P$. edulis and $P$. alata pulp, and P. edulis rinds, healthy or infected with the passion fruit woodiness virus (PWV), was investigated in phorbol 12-myristate 13-acetate (PMA)-stimulated neutrophils and purified myeloperoxidase (MPO). P. edulis rinds exhibited higher antioxidant activity, possibly correlated with the isoorientin content in $P$. edulis extracts, as determined by HPLC-UV/DAD. ${ }^{10}$

HPTLC (high performance thin layer chromatography) may represent an alternative to HPLC or LC-MS/MS, particularly in the analysis of crude plant extracts. Unlike HPLC, the HPTLC

*e-mail: janete@iqsc.usp.br procedure does not require extensive clean-up procedures even for quantitative analysis; moreover, the availability of many sensitive and selective reagents for detection and confirmation of specific classes of compounds constitutes a significant advantage of HPTLC. ${ }^{11,12}$ The European pharmacopoeia suggests the development of analytical methods requiring smaller amounts of reagents, solvents and material. ${ }^{13}$ HPTLC allows for the simultaneous analysis of numerous samples using small quantities of solvents, thus reducing both time and cost of analysis. Therefore, this technique should be taken into consideration as an alternative to HPLC. ${ }^{11}$

Despite the advantages of the HPTLC technique in the analysis of drugs and food plants, no reports on its use for the analysis of passion fruit samples are available. A method for the quantitative analysis of P. caerulea leaves by HPTLC was developed, using isoorientin as the marker. ${ }^{14}$ In a previous study, ${ }^{15}$ a HPTLC method for quantifying orientin and isoorientin from P. alata, P. edulis, P. caerulea and $P$. incarnata leaves was developed. In the same study, authors also developed a quantitative HPLC method to analyze Passiflora leaves using rutin as the standard (a widely available commercial low-cost analytical standard).

This work reports on the development of an analytical HPTLC method for the determination of isoorientin in P. edulis rinds. To illustrate the potential applications of this HPTLC method, samples infected with the PWV virus were analyzed and compared with healthy fruits. In addition, in view of the potential use of passion fruit rind by-products as a source of natural antioxidants and a possible functional food, the antioxidant (radical scavenging) capacity of passion fruit extracts was evaluated by the DPPH' (2,2-diphenyl-1-picrylhydrazyl radical) method. ${ }^{16}$

PWV is the most economically relevant viral disease of the passion fruit crop. The typical symptoms of this disease are wrinkling, deformations and blisters on the leaf surface and on rinds, reducing the productive life of an orchard from 36 to 18 months. The PWV virus also causes significantly reduced fruit production and loss of fruit quality. ${ }^{17}$ Increasing interest has focused on the study and use of by-products from the fruit and vegetable foods industry, but further studies are still needed on bioactive natural products from Brazilian agro-industrial by-products such as sugarcane wastes ${ }^{18}$ and tropical fruits crops, including passion fruit waste. 


\section{EXPERIMENTAL}

\section{Samples}

Passiflora edulis fo. flavicarpa O. Degener fruits produced by a commercial fruit grower in the municipality of Bauru, state of São Paulo, Brazil were purchased in December 2008. The plant material was identified by Dr. L. C. Bernacci (Herbarium of the Agronomic Institute of Campinas, IAC, Campinas, SP, Brazil) and a voucher specimen was deposited in the herbarium of the Agronomic Institute of Campinas, SP, Brazil (voucher number IAC 49929). The plants were evaluated individually to check for the presence of PWV in the fruit based on the typical symptoms of wrinkling, deformations and blisters on leaf surfaces and rinds. The rinds (epicarp and mesocarp) were divided into two lots for analysis: healthy rinds and rinds with typical symptoms of PWV infection. The rinds were washed, dried at $40{ }^{\circ} \mathrm{C}$ for $24 \mathrm{~h}$, ground into small pieces in a food mixer, and then sieved through a no. 16 mesh sieve to separate the material with a particle size greater than $1.2 \mathrm{~mm}$. The powdered material was stored in plastic containers protected from humidity and heat.

\section{Chemicals and standards}

HPLC grade methanol was supplied by J. T. Baker (Phillipsburg, NJ, USA). Formic acid, ethyl acetate, anhydrous glacial acetic acid (100\%), and methyl ethyl ketone were purchased from Merck (VWR, Leuven, Belgium). Water was purified in a Milli-Q system (Millipore, Bedford, MA, USA).

The reagent diphenylboric acid-2-aminoethylester was obtained from Fluka (Buchs, Switzerland) and PEG (polyethylene glycol) 400 was supplied by Merck (VWR, Leuven, Belgium). DPPH (2,2-diphenyl-1-picrylhydrazyl radical) reagent was purchased from Sigma (St. Louis, Missouri, USA). The bicinchoninic acid (BCA) protein assay kit and bovine serum albumin (BSA) were obtained from Sigma-Aldrich (Bornem, Belgium).

Standard isoorientin ( $\geq 99 \%$ purity) was obtained from Carl Roth (Karlsruhe, Germany). Rutin hydrate (95\% purity) and resveratrol ( $\geq 99 \%$ purity) were supplied by Sigma (St. Louis, Missouri, USA).

\section{Sample and standard solution preparation}

The $P$. edulis rinds extracts, infected or otherwise by PWV, were prepared as described in the literature: ${ }^{9}$ a volume of $20.0 \mathrm{~mL}$ of methanol was added to $1.0 \mathrm{~g}$ of dried and crushed rinds, after which the material was shaken for $60 \mathrm{~min}$, filtered, with the filtrate evaporated in a rotary evaporator and final volume adjusted to $2.0 \mathrm{~mL}$.

A stock solution of isoorientin was prepared in methanol at $400 \mu \mathrm{g} \mathrm{mL} \mathrm{m}^{-1}$. Methanol stock solutions of resveratrol and rutin at a concentration of $1.00 \mathrm{~g} \mathrm{~L}^{-1}$ were prepared immediately before the assays with DPPH:

\section{HPTLC analysis of samples}

Chromatographic analyses were carried out on silica gel $60 \mathrm{~F}_{254}$ HPTLC plates $(10 \times 20 \mathrm{~cm}$, silica 60 spherical particles of $7 \mu \mathrm{m}$, layer thickness $0.2 \mathrm{~mm}$; Merck, Darmstadt, Germany). Samples were placed on the plates in the form of bands, using an AS30 TLC applicator (Desaga, Heildelberg, Germany). Aliquots of extracts of healthy $P$. edulis rind $(8 \mu \mathrm{L})$, extracts of PWV infected rind (16 $\mu \mathrm{L})$, and isoorientin $(0.8,1.6,2.4,3.2$ and $4.0 \mu \mathrm{L})$ were placed on the plates. The analytical curves were built using isoorientin as the standard. The samples and standards were analyzed in quadruplicate. The width of the bands was $5 \mathrm{~mm}$ and the distance between the middle of the bands was $9 \mathrm{~mm}$. The step volume was $0.8 \mu \mathrm{L}$, applied at a rate of $30 \mathrm{~s} \mu \mathrm{L}^{-1}$, with $15 \mathrm{~s}$ intervals between applications. The contents of the plates were developed in a presaturated ( $1 \mathrm{~h}$ ) TLC chamber (Camag, Muttenz, Switzerland) using ethyl acetate:formic acid:water $(82: 9: 9 \mathrm{v} / \mathrm{v})$ as the mobile phase. The development length was $70 \mathrm{~mm}$ (development time approximately $30 \mathrm{~min}$ ). After development, the plates were dried and the derivatization carried out by immersion of the plates (one stroke) in a solution of diphenylboric acid-2-aminoethyl ester (100 mg) and PEG $400(500 \mathrm{mg})$ in methanol $(10 \mathrm{~mL})^{19}$ followed by air-drying at room temperature.

\section{Densitometric evaluation}

Plates containing methanol extracts and standards were scanned $1 \mathrm{~h}$ after derivatization, using a CD60 densitometer (Desaga, Heidelberg, Germany) under the following conditions, optimized by Pereira et al. ${ }^{15}$ for the analyses of flavonoids in Passiflora leaf extracts: scanning mode, remission-fluorescence (mercury lamp); measurement wavelength, $300 \mathrm{~nm}$ (emission filter $550 \mathrm{~nm}$ ); positive signal; slit width, $0.04 \mathrm{~mm}$; slit height, $6.0 \mathrm{~mm}$; band optimization mode; resolution $0.025 \mathrm{~mm}$; number of measurements per position, 32; signal factor, 15. Peak height measurement was utilized.

The plates were photographed $1 \mathrm{~h}$ after derivatization, using a VD40 VideoDocumentation System (Desaga) at an excitation wavelength of $366 \mathrm{~nm}$.

\section{DPPH' spectrophotometric assays for evaluation of radical scavenging capacity}

The DPPH ${ }^{\cdot}$ method described by Brand-Williams et al., ${ }^{16}$ with some modifications, ${ }^{20}$ was used to evaluate the radical scavenging capacity based on the reaction with $\mathrm{DPPH}^{*}$ and the methanol solutions of extracts and standards. This procedure was followed by monitoring the decrease in $\mathrm{DPPH}^{*}$ absorbance over a given time interval, using freshly prepared $\mathrm{DPPH}^{*}$ stock solutions.

The passion fruit rinds $(1 \mathrm{~g})$ were mixed with methanol (20 $\mathrm{mL})$ and sonicated $\left(5 \mathrm{~min}, 25^{\circ} \mathrm{C}\right)$, after which they were centrifuged $\left(10000 \mathrm{rpm}, 20 \mathrm{~min}, 25^{\circ} \mathrm{C}\right)$ and the resulting supernatant utilized for the antioxidant assay. Aliquots of extracts $(0.1 \mathrm{~mL})$ in different concentrations $\left(1,5,15,25\right.$ and $35 \mathrm{~g} \mathrm{~L}^{-1}$ of healthy rind extracts and 5, 10, 20, 30 and $40 \mathrm{~g} \mathrm{~L}^{-1}$ of PWV infected rind extracts) were mixed with $3.9 \mathrm{~mL}^{\circ}$ of $\mathrm{DPPH}^{*}$ methanol solution $(0.025$ $\left.\mathrm{g} \mathrm{L}^{-1}\right)$. The mixture was shaken vigorously and allowed to stand in the dark at room temperature for $1 \mathrm{~h}$. The same procedure was carried out with methanol solutions of rutin and resveratrol (standard compounds) in concentrations of 0.06 to $1.00 \mathrm{~g} \mathrm{~L}^{-1}$.

The decrease in absorbance of the resulting solution was monitored at $515 \mathrm{~nm}$ after $1 \mathrm{~h}$ of reaction, using a Perkin Elmer UV-Vis model Cary 5G spectrophotometer (Waltham, Massachusetts, USA). The blank solution consisted of $0.1 \mathrm{~mL}$ of methanol and $3.9 \mathrm{~mL}$ of a DPPH methanol solution in the concentration of $0.025 \mathrm{~g} \mathrm{~L}^{-1}$, and the same procedure described for the samples was carried out with the blank solution.

The percentage of scavenged $\mathrm{DPPH}^{*}$ was calculated from Equation 1.

$$
D P P H_{\text {scavenging }}^{\cdot} \%=\left(A o-A_{S} / A o\right) \times 100
$$

where $A o$ is absorbance of the blank and $A_{S}$ is absorbance of the sample at $515 \mathrm{~nm}$.

The percentage of scavenged $\mathrm{DPPH}^{*}$ was then plotted against the sample concentration to calculate graphically the amount of radical scavenging compounds required to decrease the initial $\mathrm{DPPH}^{*}$ 
concentration by $50 \%\left(\mathrm{EC}_{50}\right)$, expressed in terms of concentration $\left(\mathrm{g} \mathrm{L}^{-1}\right)$.

\section{RESULTS AND DISCUSSION}

\section{HPTLC analysis}

The conditions for the HPTLC analyses were optimized by changing the chromatographic parameters: different step volumes (0.5- $4.0 \mu \mathrm{L})$, application rates (10- $\left.30 \mathrm{~s} \mu \mathrm{L}^{-1}\right)$ and intervals between applications (10- $30 \mathrm{~s})$ were tested. In addition, different mobile phases previously described for the separation of flavonoids were tested: ethyl acetate-formic acid-water $(6: 1: 1 \mathrm{v} / \mathrm{v}),{ }^{19}$ ethyl acetate-formic acid-acetic acid-water (100:11:11:26 v/v), ${ }^{21}$ ethyl acetate-methyl ethyl ketone-formic acid-water (50:30:10:10 v/v), ${ }^{13}$ and ethyl acetate-formic acid-water $(82: 9: 9 \mathrm{v} / \mathrm{v}) .{ }^{15}$ The mobile phase ethyl acetate-formic acid-water $(82: 9: 9 \mathrm{v} / \mathrm{v})($ Figure 1) provided best separation of the flavonoids from passion fruit rind extracts, resulting in tight spots.

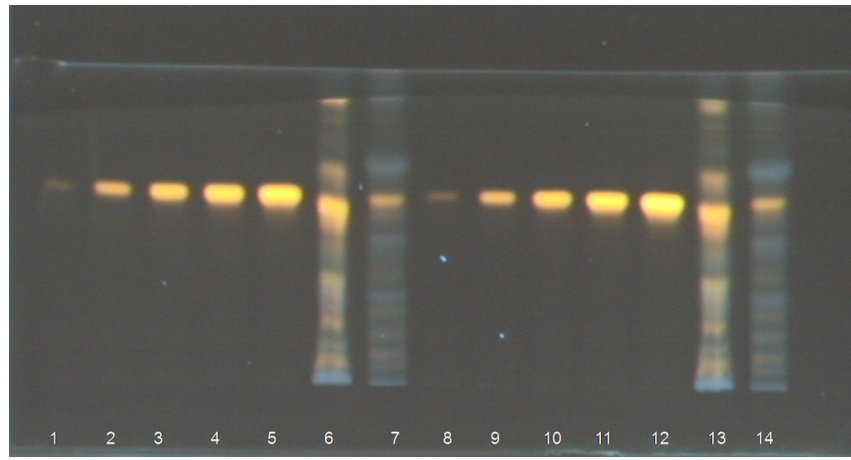

Figure 1. Photographic record of HPTLC plate treated with diphenylboric acid-2 aminoethylester-PEG 400 reagent $\left(\lambda_{\text {excitation }}=366 \mathrm{~nm}\right)$ of crude methanolic extracts and standards. Mobile phase ethyl acetate-formic acid-water $(6: 1: 1 \mathrm{v} / \mathrm{v})$. The other conditions were described in Materials and Methods. Lane number: 1-5, isoorientin $(0.8,1.6,2.4,3.2,4.0 \mu \mathrm{L}) ; 6$, healthy rinds of P. edulis $(8.0 \mu \mathrm{L}) ; 7$, P. edulis rinds with PWV $(16.0 \mu \mathrm{L}) ; 8-14$ duplicate of standards and extracts from 1-7, respectively.

The correlation between structure and fluorescence of flavonoids was described by Homberg and Geiger, ${ }^{22}$ and the fluorescence enhancement after the reaction with diphenylboric acid-2-aminoethylester is determined by the nature, number and position of flavonoid substituents.

The passion fruit rind extracts showed several flavonoid spots, including spots that appeared after derivatization, strong yellow fluorescence under long-wave UV, indicating predominance of luteolin derivatives (isoorientin), mainly in the healthy rinds (Figure 1). The blue bands, found mainly in infected rinds, indicated the presence of phenolic carboxylic acids, which occur frequently in plant material containing flavonoids. ${ }^{21}$

The selectivity of the reagents for fluorescence detection in HPTLC with densitometry may be useful in routine quantitative analyses of flavonoids in complex mixtures such as passion fruit rind extracts, for example, to confirm specific classes of compounds. As the fluorescence emission of flavonoids may occur in a broad color spectrum after derivatization, their selective detection involves measuring the fluorescence radiation emission of each spot and using distinct standards for calibration plots. By comparison with flavonoid standards (isoorientin, orientin and rutin), a very pale band with $\mathrm{Rf}$ and a fluorescence color identical to orientin was found, while rutin was not detected by HPTLC in the studied samples extracts.
However, $C$-glycosylflavone isoorientin (Figure 2) was identified in passion fruit rind extracts and the intensity of fluorescence of the spots was adequated for quantitative densitometric analysis and therefore chosen as the standard.<smiles>O=c1cc(-c2ccc(O)c(O)c2)oc2cc(O)c(Cl)c(O)c12</smiles>

Figure 2. Structure of isoorientin. Glu: glucose

The densitometric analysis was carried out with detection at 300 $\mathrm{nm}$ and filter at $550 \mathrm{~nm}$ : these conditions provided the maximum fluorescence intensity and were selective for the yellow fluorescence corresponding to luteolin derivatives such as isoorientin. The isoorientin in passion fruit rind extracts was quantified by the external standard method, with the analytical curve $(y=-48.85607+208.8236$ $\mathrm{x}, r=0.9988$ ) showing good linearity.

The isoorientin content in healthy P. edulis rinds extract was found to be three-fold higher than in PWV infected rinds extract (Table 1); the infected and healthy rinds were purchased on the same day from the same place. This suggests that the HPTLC method can be used for further agronomic or metabolomic studies of plants infected with the PWV virus using isoorientin as a marker.

Table 1. Quantification of isoorientin in the passion fruit rinds samples using HPTLC method

\begin{tabular}{lccc}
\hline Samples & \multicolumn{3}{c}{ Isoorientin concentration } \\
\cline { 2 - 4 } & $\left(\mathrm{mg} \mathrm{L}^{-1}\right)^{\mathrm{a}} \pm \mathrm{s} . \mathrm{d}$. & $\left(\mathrm{mmol} \mathrm{L}^{-1}\right)^{\mathrm{b}} \pm \mathrm{s} . \mathrm{d}$. & $\left(\mathrm{mg} \mathrm{g}^{-1}\right)^{\mathrm{c}} \pm \mathrm{s} . \mathrm{d}$. \\
\hline $\begin{array}{l}\text { P. edulis } \\
\text { healthy rinds }\end{array}$ & $92.275 \pm 0.610$ & $0.206 \pm 0.001$ & $1.230 \pm 0.008$ \\
$\begin{array}{l}\text { P. edulis rinds } \\
\text { infected by PWV }\end{array}$ & $28.931 \pm 0.346$ & $0.064 \pm 0.001$ & $0.964 \pm 0.011$ \\
\hline
\end{tabular}

${ }^{a} \mathrm{mg}$ isoorientin $\mathrm{L}^{-1}$ rinds extract; ${ }^{\mathrm{b}} \mathrm{mmol}$ isoorientin $\mathrm{L}^{-1}$ rinds extract; ${ }^{\mathrm{c}} \mathrm{mg}$ isoorientin $\mathrm{g}^{-1}$ dried rinds; s.d.: standard deviation

The HPTLC technique exhibited several advantages, such as simultaneous analysis of the extracts and low solvent consumption. The HPTLC method (120 min) was almost seven times faster than the HPLC method (700 min) due to the possibility of analyzing several samples simultaneously on a single HPTLC plate. The amount of solvent consumed in the HPTLC method $(12 \mathrm{~mL})$ was almost eight-fold less than that used in the HPLC method $(98 \mathrm{~mL})$, indicating that HPTLC is an alternative technique for analyzing large numbers of samples, as is the case of agronomic studies such as those reported by Reimberg et al..$^{23}$ or in routine analyses (quality control).

\section{DPPH` scavenging capacity assay}

The antioxidant capacity of passion fruit rind extracts was evaluated in terms of hydrogen donation or radical scavenging ability, using the DPPH' method developed by Brand-Williams et al. ${ }^{16}$ with a few modifications ${ }^{20}$ and rutin and resveratrol as reference antioxidant compounds. Resveratrol was chosen as one of the standards due to its correlation with the purported health benefits of red wine as a functional food, although the concentration used in this assay was higher than in Brazilian red wine $\left(2.57 \mathrm{mg} \mathrm{L}^{-1}\right)^{24}$ or French red wine 
(5.06 mg L $\left.\mathrm{m}^{-1}\right) .{ }^{25}$ Rutin was used as an analytical standard because it is an inexpensive flavonoid widely available commercially in Brazil.

$\mathrm{DPPH}^{*}$ absorbance with antioxidant compounds after $1 \mathrm{~h}$ of reaction was measured and the absorbance value of each sample was used to calculate the percentage of scavenged $\mathrm{DPPH}^{\cdot}$ and thus determine the $\mathrm{EC}_{50}$ value (Table 2), a parameter that corresponds to the amount of antioxidant required to decrease the initial $\mathrm{DPPH}^{\circ}$ concentration by $50 \%$. Several tests using different concentrations of each extract were performed to determine the best concentration range to reach $\mathrm{EC}_{50}$ values.

Table 2. Results of the $\mathrm{DPPH}^{\cdot}$ assay of the passion fruit rinds samples and standards compounds

\begin{tabular}{lccc}
\hline Samples & $\begin{array}{c}\text { Concentration } \\
\left(\mathrm{g} \mathrm{L}^{-1}\right)\end{array}$ & $\begin{array}{c}\text { \% scavenged } \\
\mathrm{DPPH}^{*}\end{array}$ & $\begin{array}{c}\mathrm{EC}_{50} \pm \mathrm{s.d} . \\
\left(\mathrm{g} \mathrm{L}^{-1}\right)\end{array}$ \\
\hline P. edulis healthy rinds & $1.00-35.00$ & $9.10-63.30$ & $25.93^{*} \pm 1.80$ \\
$\begin{array}{l}\text { P. edulis rinds infected } \\
\text { by PWV }\end{array}$ & $5.00-40.00$ & $10.70-61.30$ & $31.35^{*} \pm 1.15$ \\
Resveratrol & $0.06-1.00$ & $11.60-80.60$ & $0.30 \pm 0.01$ \\
Rutin & $0.06-1.00$ & $35.20-94.00$ & $0.10 \pm 0.01$ \\
\hline
\end{tabular}

s.d.: standard deviation $(\mathrm{n}=3)$; * mean values differ to each other (Student's t-test, $p=0.05$ ).

The higher the samples' consumption of DPPH' the lower the $\mathrm{EC}_{50}$ and the higher the samples' antioxidant capacity. Thus, a comparison of the values indicated that healthy rind extract had a higher radical scavenging capacity $\left(\mathrm{EC}_{50}=25.93 \pm 1.80 \mathrm{~g} \mathrm{~L}^{-1}\right)$ than PWV-infected rind extract $\left(\mathrm{EC}_{50}=31.35 \pm 1.15 \mathrm{~g} \mathrm{~L}^{-1}\right)$. The standards (rutin and resveratrol) presented higher antioxidant capacity than the extracts. This difference in the antioxidant capacity of the rind extracts and standard must be attributed, at least in part, to the higher purity of the reference compounds (rutin 95\% and resveratrol 99\%), while the crude extract contains other compounds that are not necessarily proton donors, e.g., sugars, mixed with the active compounds.

The antioxidant capacity of passion fruit rinds (healthy and infected with PWV) was found to be considerably higher than in other foods such as sugarcane juice $\left(\mathrm{EC}_{50}=100.80 \pm 2.56 \mathrm{~g} \mathrm{~L}^{-1}\right)^{26}$ and passion fruit pulp $\left(\mathrm{EC}_{50}=38.50 \pm 2.28 \mathrm{~g} \mathrm{~L}^{-1}\right){ }^{27}$

The full data obtained herein and in a complementary study of the antioxidant activity on stimulated neutrophils and myeloperoxidase activity, ${ }^{10}$ suggest a direct correlation between antioxidant capacity and isoorientin content in $P$. edulis rinds. The healthy rind extracts presented higher $\mathrm{DPPH}^{*}$ scavenging ability than PWV-infected rinds, and also showed the highest isoorientin content, probably partially responsible for the scavenging capacity of the extracts.

These results are also consistent with previous studies ${ }^{28}$ demonstrating that many flavonoids, such as isoorientin and related polyphenols, contribute significantly to the antioxidant capacity of many fruits and vegetables.

\section{CONCLUSIONS}

The HPTLC technique proved suitable and reliable for the quantitative analysis of isoorientin and for differentiation among samples by fingerprint analysis. HPTLC offers several advantages, e.g., fast development of the method, good post-chromatographic visualization, ability to work with crude extracts without requiring clean-up, and simultaneous and rapid analysis of several samples. In addition, this technique consumes little solvent and generates little waste, and therefore may also be considered a "green analytical separation technique", ${ }^{29}$ indicating its potential as an alternative technique to HPLC in routine qualitative and quantitative analyses of food and plant extracts.
Antioxidant capacity can be correlated with the content of flavonoids such as isoorientin in extracts. The isoorientin content and antioxidant capacity of passion fruit rinds proved to be high, especially in the extracts of healthy rinds. This suggests the relevance of in-depth research into passion fruit rind (an industrial by-product of the fruit juice industry) as a potential source of natural antioxidants and proteins $\left(18.06 \pm 0.51 \mathrm{mg}\right.$ total proteins per $\mathrm{mL}^{-1}$ of healthy $P$. edulis rind extract). ${ }^{30}$ Therefore, the rinds could be utilized to produce flour for enrichment of ready-to-eat foods such as cookies or cereal bars, ${ }^{31}$ which would, in turn, allow for the reduction of large quantities of organic waste generated by passion fruit juice processing plants.

\section{ACKNOWLEDGEMENTS}

The authors wish to thank FAPESP (Proc. 06/59457-6 and 2010/05711-4), CAPES and CNPq, for scholarships and financial support to this work.

\section{REFERENCES}

1. Instituto de Tecnologia de Alimentos; Maracujá: cultura, matéria-prima, processamento e aspectos econômicos, ITAL: Campinas, 1994.

2. Oliveira, L. F.; Nascimento, M. R. F.; Borges, S. V.; Ribeiro, P. C. N.; Ruback, V. R.; Ciênc. Tecnol. Aliment. 2002, 22, 259.

3. Gondim, J. A. M.; Moura, M. F. V.; Dantas, A. S.; Medeiros, R. L. S.; Santos, K. M.; Ciênc. Tecnol. Aliment. 2005, 25, 825.

4. Pinheiro, E. R.; Silva, I. M. D. A.; Gonzaga, L. V.; Amante, E. R.; Teófilo, R. F.; Ferreira, M. M. C.; Amboni, R. D. M. C.; Bioresour. Technol. 2008, 99, 5561.

5. Dhawan, K.; Dhawan, S.; Sharma, A.; J. Ethnopharm. 2004, 94, 1.

6. Zeraik, M. L.; Yariwake, J. H.; Pereira, C. A. M.; Zuin, V. G.; Rev. Bras. Farmacogn. 2010, 20, 459.

7. Zeraik, M. L.; Yariwake, J. H.; Microchem. J. 2010, 96, 86.

8. Havsteen, B. H.; Pharmacol. Ther. 2002, 96, 67.

9. Ichimura, T.; Yamanaka, A.; Ichiba, T.; Toyokawa, T.; Kamada, Y.; Tamamura T.; Maruyama, S.; Biosci. Biotechnol. Biochem. 2006, 70, 718.

10. Zeraik, M. L.; Serteyn, D.; Deby-Dupont, G.; Wauters, J.-N.; Tits, M.; Yariwake, J. H.; Angenot, L.; Franck, T.; Food Chem. 2011, 128, 259.

11. Kosior, M. W.; Skalska, A.; Matysik, A.; J. Pharm. Biomed. Anal. 2005, $41,286$.

12. Vilegas, J. H. Y.; Lanças, F. M.; Wauters, J. N.; Angenot, L.; Phytochem. Anal. 1998, 9, 263.

13. European Pharmacopoeia, $6^{\text {th }}$ ed., Council of Europe: Strasbourg (EDQM), 2008.

14. Pastene, E.; Montes, M.; Vega, M.; J. Planar Chromatogr. 1997, 10, 362.

15. Pereira, C. A. M.; Yariwake, J. H.; Lanças, F. M.; Wauters, J. N.; Tits, M.; Angenot, L.; Phytochem. Anal. 2004, 15, 241.

16. Brand-Williams, W.; Cuvelier, M. E.; Berset, C.; Leben.-Wissen. Technol. 1995, 28, 25.

17. Sampaio, A. C.; Scudeller, N.; Fumis, T. F.; Almeida, A. M.; Pinotti, R. N.; Garcia, M. J. M.; Pallamin, M. L.; Rev. Bras. Fruticult. 2008, 30, 343.

18. Colombo, R.; Lanças, F. M.; Yariwake, J. H.; J. Chromatogr., A 2006, 1103, 118.

19. Brasseur, T.; Angenot, L.; J. Chromatogr. 1986, 351, 351.

20. Kuskoski, E. M.; Asuero, A. G.; Troncoso, A. M.; Mancini-Filho, J.; Fett, R.; Ciênc. Tecnol. Aliment. 2005, 25, 726.

21. Wagner, H.; Bladt, S.; Plant drug analysis: a thin layer chromatography atlas, $2^{\text {nd }}$ ed., Springer: Berlin, 1996.

22. Homberg, H.; Geiger, H.; Phytochemistry 1980, 19, 2443.

23. Reimberg, M. C. H.; Colombo, R.; Yariwake, J. H.; Rev. Bras. Farmacogn. 2009, 19, 853 . 
24. Souto, A. A.; Carneiro, M. C.; Seferin, M.; Senna, M. J. H.; Conz, A.; Gobbi, K.; J. Food Compos. Anal. 2001, 14, 441.

25. Goldberg, D. M.; Yan, J.; Ng, E.; Diamandis, E. P.; Karumanchiri, A.; Soleas, G. J.; Amer. J. Enol. Viticult. 1995, 46, 159.

26. Vila, F. C.; Colombo, R.; Lira, T. O.; Yariwake, J. H.; J. Braz. Chem. Soc. 2008, 19, 903.

27. Ferreira, R. de Q.; Zeraik, M. L.; Lira, T. O.; Yariwake, J. H.; Avaca, L. A.; J. Braz. Chem. Soc., submitted.
28. Ko, F. N.; Chu, C. C.; Lin, C. N.; Chang, C. C.; Teng, C. M.; Biochim. Biophys. Acta 1998, 1389, 81.

29. Koel, M.; Kaljurand, M.; Crit. Rev. Anal. Chem. 2011, 41, 2.

30. Zeraik, M. L.; Yariwake, J. H.; Wauters, J. N.; Angenot, L.; Franck, T.; Serteyn, D.; Resumos do XX Congresso Italo-Latinoamericano de Etnomedicina- SILAE, Fortaleza, Brasil, 2011.

31. Ishimoto, F. Y.; Harada, A. I.; Branco, I. G.; Conceição, W. A. S.; Coutinho, M. R.; Rev. Cienc. Exatas Nat. 2007, 9, 279. 